\title{
International Capital Inflow and Sub-Saharan African Economy: Does Capital Inflow Lead Growth?
}

\author{
Ajisafe Rufus Adebayo ${ }^{\rtimes}$ \\ Okunade Solomon Oluwaseun ${ }^{2}$
}

Department of Economics, Faculty of Social Sciences, Obafemi Awolowo University, Ile - Ife, Nigeria.

Email:rajisafe@oanife.edu.ng.

EEmail:0solomon2085@gmail.com

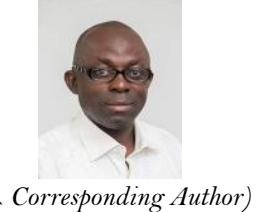

\begin{abstract}
Sub-Sahara African (SSA) countries have become more integrated with the world economy since the early 1990s leading to a surge in international capital inflows, but have also experienced sporadic downfalls in their growth rates leading to instabilities in some macroeconomic variables. This paper examined the dynamic and causal relationship between economic growth and international capital inflow in SSA using data covering the period of 1990 to 2018. Through Structural Vector Autoregression (SVAR) impulse response and variance decomposition, the study found a positive relationship between growth and international capital inflow in SSA. It also found negative relationships between macroeconomic instability and economic growth; and macroeconomic instability and international capital inflow in SSA. In addition, through VAR Granger Causality or Block Exogeneity Wald Tests, the study found a unidirectional causal relationship running from growth to international capital inflow in SSA. The study also found that international capital inflow did not cause economic growth but economic growth attracts international capital inflows. Therefore, the study concluded that a buoyant and viable economy provides conducive business environment for international investors better than less viable economy. Thus, the study recommended that governments and policy makers in SSA should put in place policies that will promote economic growth to attract more international capital inflows which would augment the scarcely available domestic capital resources most especially in terms of knowledge, skills and other technological advancement, that would later translate into further economic growth in SSA region.
\end{abstract}

Keywords: International capital inflow, Growth, Macroeconomic instability, FDI, Structural vector autoregression, Sub-Sahara Africa. JEL Classification: F36; F43.

Citation | Ajisafe Rufus Adebayo; Okunade Solomon Oluwaseun (2020). International Capital Inflow and Sub-Saharan African Economy: Does Capital Inflow Lead Growth? Growth, 7(1): 26-34. History:

Received: 30 June 2020

(2)

Revised: 3 August 2020

Published: 14 September 2020

Licensed: This work is licensed under a Creative Commons Attribution 3.0 License (cc)

Publisher: Asian Online Journal Publishing Group
Acknowledgement: Both authors contributed to the conception and design of the study.

Funding: This study received no specific financial support

Competing Interests: The authors declare that they have no conflict of interests.

Transparency: The authors confirm that the manuscript is an honest, Transparency: The authors confirm that the manuscript is an honest,
accurate, and transparent account of the study was reported; that no vital accurate, and transparent account of the study was reported; that no vital
features of the study have been omitted; and that any discrepancies from the features of the study have been omitte
study as planned have been explained.

Ethical: This study follows all ethical practices during writing.

\section{Contents}

1. Introduction

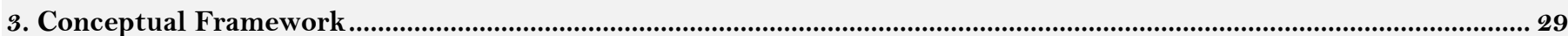

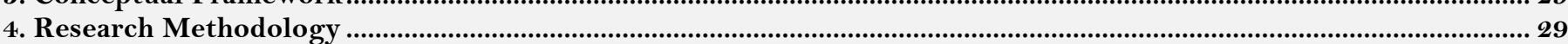

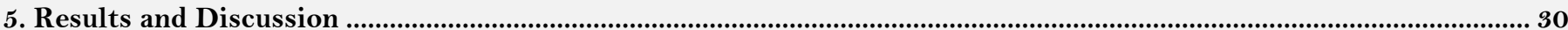

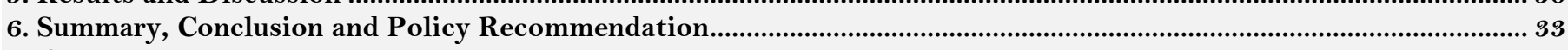

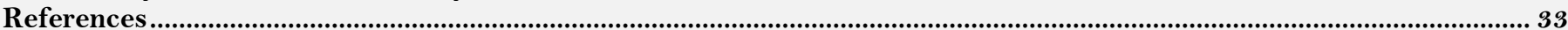




\section{Contribution of this paper to the literature}

The relationship between international capital inflows and economic growth in developed countries has received a great deal of attention, but this relationship is rarely researched in SSA region. Thus, this present study adds more substance to the extant literature by investigating dynamic and causal relationship between economic growth and international capital inflow in SSA region, previously neglected in the literature.

\section{Introduction}

The recent global financial crisis has ignited the quest to explain the dynamic relationship between financial capital inflows and growth in developing countries. In the aftermath of financial crisis, many academics and policymakers have begun to question the widely supported theoretical view that there is a positive association between capital inflows and economic growth in both developed and developing countries. The experience of global economic and financial crisis especially in the mid-1990s and 2000s has called for a reassessment of the linkage between capital inflows and growth (Cecchetti \& Kharroubi, 2012). Although, in theory, there are a number of direct and indirect channels through which international capital inflows should increase economic growth. On the direct channel, international capital inflows, through Foreign Direct Investment (FDI) should create lasting investment opportunities for both the investors and host country. These investments would contribute directly to the gross domestic products of the host country. Indirectly, foreign capital inflows have the tendency to stimulate the economy through an increase in employments and the development of human capital as a result of increased access to management expertise, skills and new technologies (Corporate Finance Institute, 2019). This may be facilitated by financial openness as advocated by new growth theories in the face of slow economic growth rate in developing countries (Kose, Prasad, \& Terrones, 2009) especially in Sub-Sahara African (SSA) countries.

Sub-Sahara African countries have become more integrated with the world economy since the early 1990s. As a result, these countries have experienced various degree of capital flows. Remarkably, African region has witnessed a surge in capital inflows especially in 1990s (Akinlo, 2003) such that foreign direct investment inflows (FDI) reached the new heights during the period as a result of opening up their economies into international financial markets (Mcmillan, Rodrik, \& Verduzco-Gallo, 2014). However, Prasad, Rogoff, Wei, and Kose (2007) argues that the whopping sum of international private gross capital flows of developing countries are accounted for by the relatively small group of more financially integrated (MFI) economies, whereas less financially integrated countries (LFI), where majority of SSA countries unarguably belong, attract very small amount of private capital flows, especially foreign direct investment to their economies especially in the 1990 s.

According to endogenous growth literature, capital inflows can contribute to growth via knowledge and technology transfers from foreign partners to the local agents in recipient countries. Through foreign direct investment (FDI), foreign technological innovations are entrenched in the capital goods which are imported by foreign companies. The importation of these goods through FDI can potentially accelerate the technological progress in the host countries (Borenzstein, Gregorio, \& Lee, 1998). On one hand, FDI is expected to supplement the existing stock of knowledge in SSA countries through labour training and skills acquisitions. It will also promote productivity growth through the introduction of alternative management practices and organizational arrangements on the other hand (Akinlo, 2003).

Since the early period of 1990s, financial openness has been marked by a surge in capital inflows among industrial countries and, more notably, between industrial and developing countries. However, while these capital inflows have been associated with high growth rates in some developing countries, a number of countries especially in SSA have experienced sporadic downfalls in their growth rates vis-à-vis the occurrence and re-occurrence of financial crises over the same period leading to instabilities in some important macroeconomic variables (Prasad et al., 2007). This macroeconomic instability was more pronounced in the high rate of inflation in SSA countries; this is evident in Figure 1. The macroeconomic instability proxied by inflation rate was always and everywhere overwhelmingly greater than the growth rate of SSA economy except for some periods like 2004 and 2010 when GDP growth rate outstripped inflation rate. The yearly comparative analysis in Figure 2 showed that macroeconomic instability as indicated by high rate of inflation has continuously hampered the rate of growth in SSA countries and made the inflows of capital ineffective in spurring economic growth in the region. The highlighted problem has generated an intense debate in both academics and policymakers about the effects of financial capital inflows on growth of developing economies, especially in SSA countries being the major recipients of capitals and other resources flowing as a result of opening up.

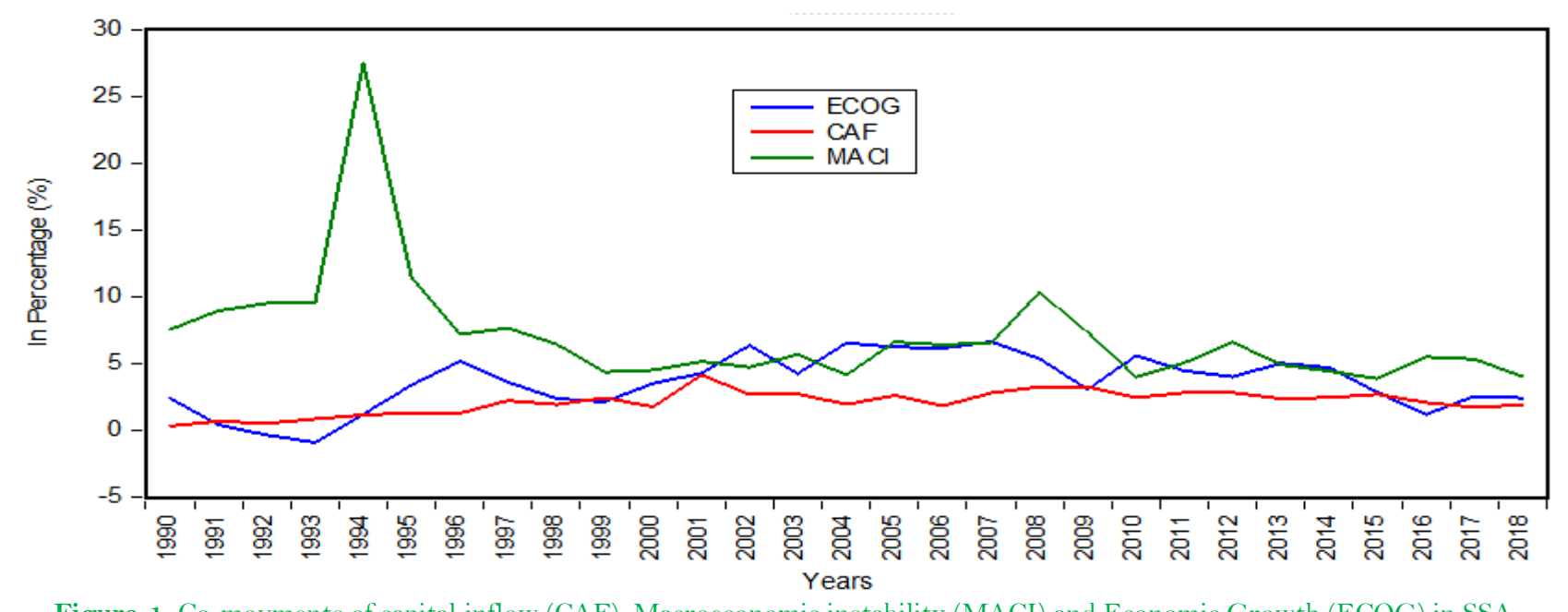

Figure-1. Co-movments of capital inflow (CAF), Macroeconomic instability (MACI) and Economic Growth (ECOG) in SSA Source: World Development Indicator, 2019. 


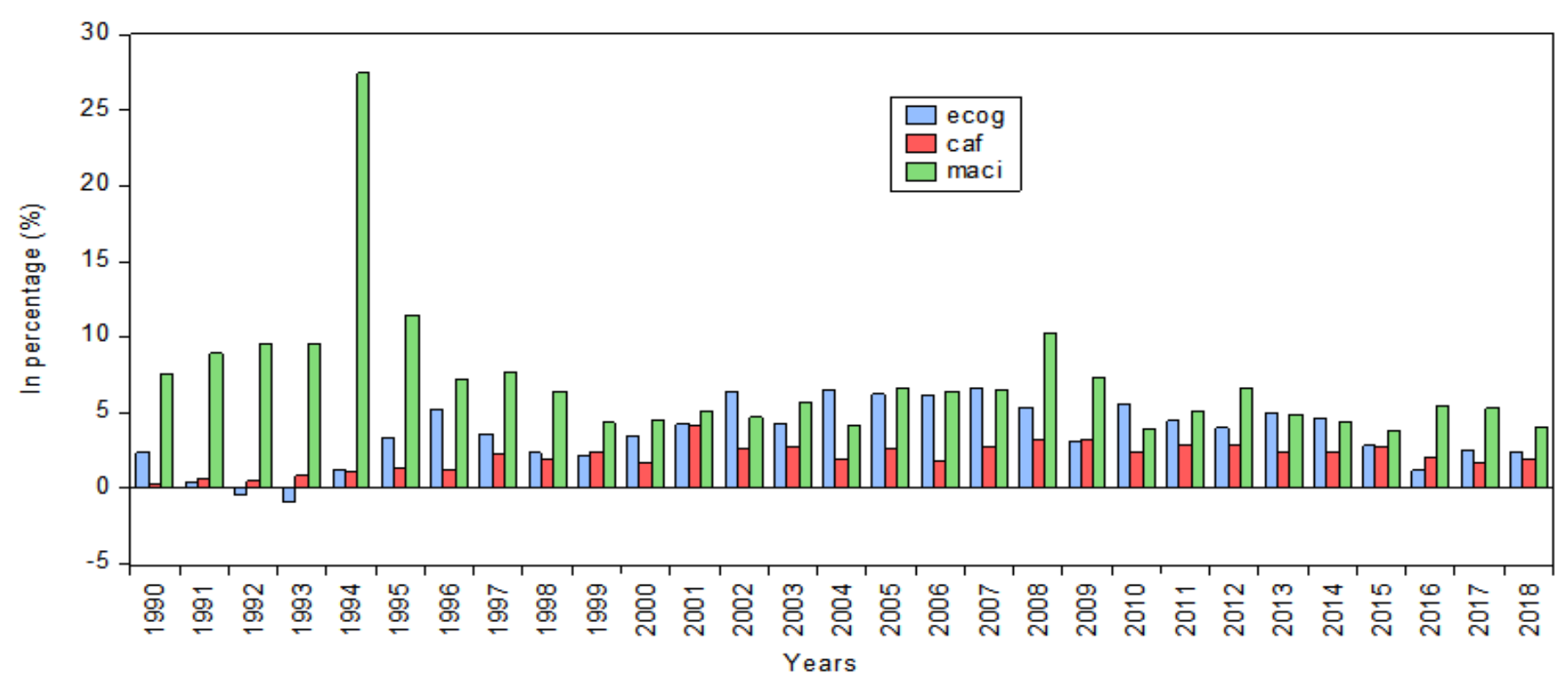

Figure-2. Yearly comparative analysis of capital inflow (CAF), Macroeconomic instability (MACI) and Economic Growth (ECOG) in SSA Source: World Development Indicator, 2019.

In addition, a key feature of international capital inflows is that the components of these flows differ significantly in terms of volatility (Kose et al., 2009; Prasad et al., 2007). Specifically, borrowings and portfolio flows are substantially more volatile than foreign direct investment. Prasad et al. (2007) opines that the structure of capital flows can have a significant influence on a country's susceptibility to financial crises. However, international capital flow may be detrimental to growth and development of a nation or region because increased capital flows from foreign countries as a result of financial integration may expose the recipient country to crises which have negative effects on growth (Karadam \& Ocal, 2014). This occurs since the recipient countries, especially African and other developing countries lack quality institutions, developed financial markets and stable macroeconomic policies like their counterpart developed countries. In addition, capital inflows such as FDIs may also weaken domestic investment since major multinational companies do repatriate their profits back to the mother countries.

The above evidence shows the existence of controversy as regards the relationship between economic growth and international capital inflows in developed and developing countries. In addition, evidences from literature have also supported the controversy about the causal relationship between economic growth and international capital inflows. For instance, a significant number of studies (Adams \& Klobodu, 2017; Carp, 2014; Karadam \& Ocal, 2014) revealed that a buoyant and prosperous economy is a prerequisite for attracting foreign capital inflows as foreign investors would consider profitability and returns before channeling their investments in a particular country while other authors were of the opinions that international capital inflows especially FDIs were significantly helpful to ensure economic growth in less developed countries (see (Ahmed \& Mmolainyane, 2014; Akinlo, 2003; Akobeng, 2016; Batu, 2017; Varela, 2018)). Thus, whether fluctuations in international capital inflows especially changes in foreign direct investment as a result of macroeconomic instability cause a significant change in economic growth in $\mathrm{SSA}$ region remains a relevant research question. The causal relationship between economic growth and international capital inflow needs to be empirically established in the context of SSA region. Thus, the need for this study.

The objective of this present study is to examine the dynamic and causal relationship between economic growth and international capital inflow in SSA region using data covering the period of 1990 to 2018.

\section{Literature Review}

Studies have explored the relationship between economic growth and capital flows in developed and developing countries. Kandil and Trabelsi (2015) examined the macroeconomic effects of capital flows as a result of financial liberalization on macroeconomic variables in a multivariate vector autoregression (VAR) framework during the period of 1989 to 2009 in Turkey. The study found that shock in capital flows did not generate significant changes in real output in pre-crisis period but the significant positive effects real GDP in post-crisis period. The responses of consumer price inflation to capital inflows shocks was almost insignificant in pre-crisis period while it was significant and negative in the first and second quarter of post-crisis period. The study therefore concluded that capital flows had differential effects on the Turkish economy before and after the crisis in 2001 and that capital flows had significant effects on macroeconomic performance, especially during the post-crisis period.

In a country specific study, Ogbuagu and Ifionu (2015) examined the impact of capital flow and human capital development on economic growth in Nigeria using annual time series data covering the period of 1990 to 2012. The study employed pairwise granger causality and dynamic autoregressive model. The study found no causality among capital flow (proxied by de jure and de facto measures of capital openness), human capital development (education expenditure and health expenditure) and economic growth in Nigeria. As regards the impact on economic growth, the study found that capital flows (proxied by de jure) have a significant impact on economic growth but foreign direct investment and foreign portfolio investment have no significant impact on economic growth in Nigeria. Thus, the study concluded that poor causal relationship among variables of interest could be as a result of lack of stable and competitive macroeconomic environment, well regulated financial sector and an excellent corporate governance environment in Nigeria which will ensure high institutional quality.

Bai (2013) analyzed the behaviour of gross capital flows in a business cycle for 103 countries divided into three groups, lower-middle-income, upper-middle-income, and high-income countries between the periods of 1970 and 2009. Through trend analyses, the study found that both gross capital inflows and outflows increase relative to GDP trend over period of time. It was also found that gross inflows and outflows are positively correlated, 
especially for high-income countries. The study concluded that decline of capital flows (direct investment, portfolio, and other investments) during crises was observed.

Also, Reinhardt, Ricci, and Tressel (2013) explored the role of capital account restrictions in shaping capital flows at various stages of economic development. Based on various countries' characteristics, the study confirmed the prediction of the neoclassical theory that less developed countries tend to experience net capital inflows and more developed countries tend to experience net capital outflows. Moreover, Alfaro, Kalemli-Ozcan, and Sayek (2009) examined the effect of foreign direct investment (FDI) on economic growth through total factor productivity (TFP) for 62 countries from 1975 to 1995. The study employed ordinary least squares (OLS) method for cross-country analysis and found that FDI did not have significant positive impact on growth but the interactions between FDI and financial sector development had significant positive impact on growth. Therefore, the study concluded that factor accumulation or physical and human capital does not seem to be the main channel through which countries benefit from FDI. Instead, countries with well-developed financial markets gain significantly from FDI through TFP improvements.

By estimating models for different income groups, Mallick and Moore (2008) empirically investigated the effect of financial capital flows on economic growth during the period 1970 to 2003 for a panel of 60 developing countries within the framework of endogenous growth. The study employed Generalized Method of Moments (GMM) and found private FDI flows had beneficial complementarity effects on the domestic capital formation (investment) across all income-group countries. Also, the official financial flows was positively related to investment in the middle income economies, but not in the low income countries. Thus, the study concluded that misallocation of official inflows remained evident in the low income countries, even though the aid-growth nexus was buttressed in the middle income countries.

\section{Conceptual Framework}

Conceptually, international capital inflows may be substantially beneficial for developing countries by enhancing efficiency, promoting financial sector competitiveness and thereby improving growth and development. At a macroeconomic level, capital inflows may enable countries to fund welfare-enhancing current account imbalances by facilitating greater productive investment and consumption smoothing thereby leading to economic growth. However, despite these positive externalities, capital inflows volatility that usually accompanies financial openness can lead to financial and macroeconomic instability by crushing domestic financial markets, making financial system vulnerable and stretching the capacity of macroeconomic policies to adjust; with overall tendency of retarding economic growth of the host country (Carp, 2014). Also, SSA countries have become more integrated with the world economy since the early 1990s leading to a surge in international capital inflows, but have also experienced sporadic downfalls in their growth rates leading to instabilities in some macroeconomic variables. This is coupled with the occurrence and re-occurrence of financial crises. The major issue that emanated from the above evidence is that, like controversial theoretical predictions, empirical findings are also mixed concerning the relationship between capital inflow and economic growth. Moreover, majority of the studies that have extensively focused on the linkage between capital inflows and economic growth were conducted on developed and emerging economies, leaving African region that was also severely affected by financial crises as a result of financial openness, out of this empirical debate. Also, these theoretical and empirical controversies coupled with the effect of global financial crisis have mandated the need to re-examine the dynamic relationship between international capital inflows and economic growth in SSA region for the purpose of policy implications. Hence, these issues constitute some gaps which this study intends to fill.

This paper would contribute to literature in three folds. First, it provided empirically evidence on the dynamic relationships between economic growth and international capital inflow in SSA region. Second, it presented causal relationship between economic growth and international capital inflow in SSA region to provide the roadmap to achieving economic growth and attract international capital inflow in the region by providing an overview of the linkages between economic growth and international capital inflow in the phase of macroeconomic fluctuations of different forms. And lastly, the study employed structural autoregression (SVAR) as a modern methodology which based its tenets on economic theories, and thus meaningful economic implications were inferred from the results. Other researchers have employed various estimation techniques, such as simple regression analyses, multiple regressions that could not capture the dynamic relationship between the variables; and simple VAR analysis that is a-theoretical in nature, and which is not structured on existing economic theories.

\section{Research Methodology}

The study took the advantage of the aggregated time series data of the SSA region provided in the World Bank's World Development Indicators, and employed annual secondary data from 1990 to 2018 on economic growth proxied by GDP growth, international capital inflows proxied by FDI flows as a share of GDP and macroeconomic instability measured by inflation rate, which were sourced from World Development Indicator, 2019 edition. The study employed Structural Vector Autoregression (SVAR) model to explain the dynamic and causal relationship among capital flows macroeconomic instability and economic growth in SSA region. The SVAR model incorporates economic theories into modelling structure and depicts the interrelationship among economic variables in an economy. One of the major strength of SVAR techniques is the fact that it takes into consideration the structure and dynamic of the economy being studied. In it general form, SVAR can be written as:

$$
A_{0} y_{t}=A_{1} y_{t-1}+\ldots \ldots \ldots \ldots+A_{k} y_{t-k}+C D_{t}+e_{t}
$$

Where $\mathrm{y}_{\mathrm{t}}=\left(\mathrm{y}_{1 \mathrm{t}}, \mathrm{y}_{2 t}, \ldots \ldots . . \mathrm{y}_{\mathrm{nt}}\right)$ is an $\mathrm{nx} 1$ vector of endogenous variables, and $\mathrm{A}_{\mathrm{i}}$ and $\mathrm{C}$ are parameter matrices of $\mathrm{n}$ $\mathrm{x} \mathrm{n} . \mathrm{D}_{\mathrm{t}}$ consists all deterministic variables which may contain a constant, linear trend, seasonal variables as well as other specified dummy variables. Given the dynamic nature of the SSA economy, the SVAR model is calibrated with some modification to capture the features of the SSA economy such as slow growth rate, unstable rate of inflation, partial openness to foreign capital inflows, and so on.

The model for this study is represented by a component vector $\left(\mathrm{y}_{\mathrm{t}}\right)$ of three endogenous variables defined as: 


$$
y_{t}=\left(\begin{array}{lll}
E C O G \quad C A F \quad M A C I
\end{array}\right)
$$

Where ECOG is the GDP growth rate, a proxy to economic growth; CAF is the international capital inflow proxied by foreign direct investment flows as a share of GDP; and MACI is inflation rate, a proxy to macroeconomic instability.

From Equation 2, all the variables are in level form. In order to achieve identification of the SVAR, this study draws from the theoretical and empirical literature. Given that matrix B is diagonal and of order $3 \times 3$. The matrix of contemporaneous relationship (Matrix B) has the following non-recursive structure. It must be noted that macroeconomic theory forms the basis of imposing restrictions on the B-matrix below. The non-recursive identification scheme is one of the most commonly used method in the literature as it easily restricts the matrix of contemporaneous relationship (Matrix B) given the theoretical underpinnings. Using the formula for imposing restriction, $\left(\frac{n^{2}-n}{2}\right)$; where $\mathrm{n}$ is the number of endogenous variables.

The first line in Equation 3 is an individual equation for economic growth (ECOG) which shows that it is a function of international capital inflow (CAF) and macroeconomic instability (MACI). International capital inflow could stimulate growth by increasing the local investment rate and the investments connected with positive spillovers (Bailliu, 2000). Also, technological progress and organizational knowledge brought about by capital inflows tend to improve the economic performance of a country or region. Macroeconomic instability proxied by inflation rate could also retard growth by lowering the purchasing power parity in a given economy. The second line in an individual equation for international capital inflow (CAF) which equally depends on the performance of the economy (ECOG) in the SSA. That is, an improved economy may attract foreign investments.

$\boldsymbol{B}=\underset{M A C I}{\operatorname{ECOG}}\left[\begin{array}{ccc}1 & b_{12} & b_{13} \\ b_{21} & 1 & 0 \\ 0 & 0 & 1\end{array}\right]$

In addition, the study assumes no contemporaneous relationship between economic growth and macroeconomic instability, and between inflation rate between international capital inflow especially the FDI following many empirical studies that reported no association between economic growth and inflation rate (See (Bai, 2013; Bailliu, 2000; Batu, 2017; Beckmann \& Czudaj, 2017)). That is, neither economic growth nor capital inflow is expected to affect macroeconomic instability. This is depicted in the third line of Equation 3. The non-recursive identification scheme above identified three restrictions and the $b_{12}, b_{13}$ and $b_{21}$ symbolize the freely estimated parameters. To analyse the model in Equation 2, both impulse response function and variance decomposition are used. According to Christiano (2006) SVAR procedure is for estimating the response of the economy to a shock since the structural VAR performs well in all of their examples and tests, and it overcomes several identified problems with the VAR approach, such as the restricted role of economic theory and the recursive form of economic structure.

The measure of economic growth of SSA region employed in this study is growth rate of GDP since it indicates the overall performance of the economy of the region. The indicator of international capital inflow employed is foreign direct investment flows. This variable is preferred because a remarkable increase in capital inflow especially foreign direct investment flows was witnessed in Africa since 1990s as a result of opening up of their economies into international financial markets (Akinlo., 2012; Mcmillan et al., 2014). The indicator of macroeconomic instability that is employed in this study is inflation rate. This variable is preferred to other variables because of its relevance in explaining economic growth and the wellbeing of the people.

\section{Results and Discussion}

In an attempt to examine dynamic and causal relationship among international capital inflow, macroeconomic instability and economic growth in SSA region, Table 1 and Table 2 present stationarity test and descriptive analysis of variables employed in the study. To test for stationarity, Augmented Dickey-Fuller (ADF) and Kwaitkowski-Phillips-Schmidt-Shin (KPSS) at constant were used in Table 1. The results in Table 1 reveal that the GDP growth is stationary at first difference while FDI inflows and inflation rate are stationary at level in both tests. Thus, economic growth proxied by GDP growth rate undergone stationarity process once before estimating the main model of SVAR and VAR Granger or Block Exogeneity causality test.

Moreover, the descriptive analysis of variables shows that mean and median of all the variables in the data set presented in Table 2 lie within the maximum and minimum values. Economic growth and macroeconomic instability are positively skewed except capital inflow. The kurtosis statistic showed that CAF is platykurtic which implies its distribution is flatter relative to normal distribution while other variables such as ECOG and MACI are greatly peaked relative to the normal distribution. Moreover, the results in Table 2 show that MACI is the most volatile variable while $\mathrm{CAF}$ is the least volatile given its standard deviation from mean value of 4.463 and 1.002 respectively. Skewness statistics shows that ECOG and MACI are positively skewed while CAF is negatively skewed. Finally, the Jarque-Bera statistics significantly rejected the null hypothesis of normal distribution for every variable at 5 percent except for all the variables. 
Table-1. The Results ADF and KPSS Tests

\begin{tabular}{c|c|c|c|c|c|c}
\hline \multicolumn{9}{|c|}{ ADF } & \multicolumn{3}{c}{ KPSS } \\
\hline Variable & Level & First Diff & Status & Level & First Diff & Status \\
\hline ECOG & -2.4373 & $-6.2281^{* * *}$ & $\mathrm{I}(1)$ & 0.3220 & $0.3227^{* * *}$ & $\mathrm{I}(1)$ \\
\hline CAF & $-2.7857^{*}$ & & $\mathrm{I}(0)$ & $0.4925^{* *}$ & & $\mathrm{I}(0)$ \\
\hline MACI & $-2.8921^{*}$ & & $\mathrm{I}(0)$ & $0.4976^{* *}$ & & $\mathrm{I}(0)$ \\
\hline
\end{tabular}

Note: $\left.(*),{ }^{* *}\right)$ and $(* * *)$ indicates the probability value is significant at $10 \%, 5 \%$ and $1 \%$ level respectively. ECOG, CAF and MAC represents economic growth proxied by GDP growth, international capital inflows proxied by FDI flows as a share of GDP and macroeconomic instability measured by inflation rate respectively.

Table-2. Summary of descriptive statistics.

\begin{tabular}{c|c|c|c|c|c|c|c|c|c}
\hline Variable & Mean & Median & Maximum & Minimum & Std. Dev. & Skewness & Kurtosis & Jarqu-Bera & Probability \\
\hline ECOG & 3.782705 & 3.652984 & 11.69729 & -1.411702 & 2.574661 & 0.706785 & 4.907245 & 6.340234 & 0.0419 \\
\hline CAF & 2.268598 & 2.399622 & 4.560747 & 0.416933 & 1.001509 & -0.048689 & 2.788254 & 0.061109 & 0.9699 \\
\hline MACI & 7.574891 & 6.695265 & 26.08157 & 3.440567 & 4.462663 & 2.780370 & 12.07013 & 127.3378 & 0.0000 \\
\hline \multicolumn{2}{l}{ Note: ECOG, CAF and MACI represents economic growth proxied by GDP growth, international capital inflows proxied by FDI flows as a share of GDP }
\end{tabular}

Note: ECOG, CAF and MACI represents economic growth proxied by
and macroeconomic instability measured by inflation rate respectively.

From Table 3, the optimal lag length of one is chosen by all criteria. Therefore, the model is estimated with optimum lag length of one. Moreover, the Structural Vector Autoregressive (SVAR) model stated in equation 1 is estimated and the parameters in the matrix of contemporaneous relationship in equation are evaluated.

\begin{tabular}{c|c|c|c|c|c|c}
\multicolumn{7}{c}{ Table-3. VAR lag order selection criteria. } \\
\hline Lag & LogL & LR & FPE & AIC & SIC & HQ \\
\hline 0 & -150.7325 & NA & 73.51958 & 12.81104 & 12.95829 & 12.85011 \\
\hline 1 & -135.9006 & $24.71985^{*}$ & $45.64214^{*}$ & $12.32505^{*}$ & $12.91407^{*}$ & $12.48131^{*}$ \\
\hline 2 & -130.9147 & 7.063307 & 66.56957 & 12.65956 & 13.69035 & 12.93303 \\
\hline 3 & -122.4247 & 9.904944 & 77.50478 & 12.70206 & 14.17463 & 13.09273 \\
\hline
\end{tabular}

Note: * indicates lag order selected by the criterion; and LR, FPE, AIC, SIC and HQ represent sequential modified LR test statistic (each test at $5 \%$ level), Final prediction error, Akaike information criterion, Schwarz information criterion and Hannan-Quinn information criterion respectively.

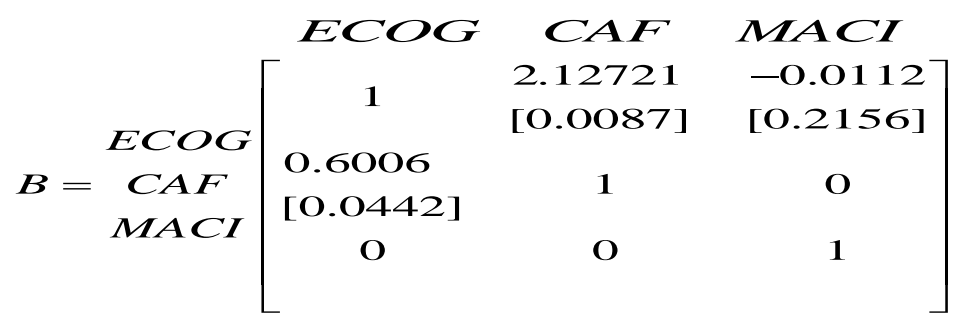

The significance of $b_{21}$ and $b_{12}$ (as given by the probability values in the parenthesis) showed that the contemporaneous dynamic relationship between economic growth and international capital inflow revealed that shocks to economic growth exert a positive response on capital inflows while capital inflow also exert positive response on economic growth. This result is validated through Impulse Response Function (IRF) and Forecast Error Variance Decomposition (FEVD) in Figure 3 and Table 4 respectively. Moreover, it has been noted in the literature that individual coefficients from vector autoregression presented in Equation 1 are difficult to interpret, therefore Impulse Response Function (IRF) and Forecast Error Variance Decomposition (FEVD) are used to examine the contemporaneous relationship among international capital inflow, macroeconomic instability and economic growth in SSA region. The impulse response function traces the dynamic responses to the effect of shock in one variable not only upon itself but also upon on all other variables while variance decomposition provides information about the relative importance of each random shock to the endogenous variables in the vector autoregression (Akinlo., 2012). The impulse response function (IRF) and the variance decomposition (VD) of the endogenous variables in the model are depicted in Figure 3 and Table 4 respectively, using the horizon of ten periods.

As it can be seen in Figure 3, the response of economic growth (ECOG) to a one standard deviation innovation in capital flows (FDI) is positive in both short run and long run period. This shows that ECOG responds positively to capital inflow during the period. Although its response was decreasing especially in the medium and long run, which implies that the effects of shocks to capital inflow on economic growth is asymptotically tending to zero in the long run. However, the response of economic growth to a one standard deviation innovation in macroeconomic instability is positive in short run but oscillates around zero in medium and long run period. Similarly, the response of capital inflow proxied by foreign direct investment to a one standard deviation innovation in economic growth proxied by gross domestic product growth is positive in both short run and long run period. This shows that capital inflow also responds positively to shocks in economic growth in the period. The response of capital inflow to a one standard deviation innovation in macroeconomic instability is negative in short run but becomes uncertain in medium and long run period since its response oscillates around zero throughout the periods. Lastly, the response of macroeconomic instability proxied by inflation rate to a one standard deviation innovation in both economic growth and capital inflow is negative throughout the periods. This shows that the effect of macroeconomic uncertainty is negative on both economic growth and capital flows in SSA region.

Apart from the impulse response function, variance decomposition is also used to trace the shock of each variable to the endogenous variables in the vector autoregression. From Table 4, the results show that apart from ECOG 'own' shock, shock to capital inflow is the most important source of forecast error variance from the second year. It accounts for $4.76 \%$ of the forecast error variance in ECOG and the influence progresses in the longer horizons and increase just to $8.77 \%$ in the tenth year. The results also reveal that ECOG's own shocks accounted for $100 \%, 90.7 \%$ and $89.9 \%$ variation in itself in the first, fifth and tenth periods respectively, implying that ECOG 
own shocks fade out in the long run. Also, macroeconomic instability accounts for a negligible percentage of forecast error variance in ECOG. It accounts for only $0 \%, 1.39 \%$ and $1.34 \%$ in first, fifth and tenth period respectively.

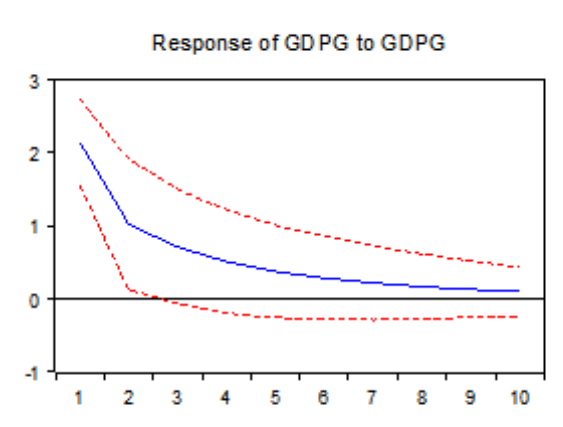

Respons to Cholesyone S.D. Innovations \pm 2 S.E.
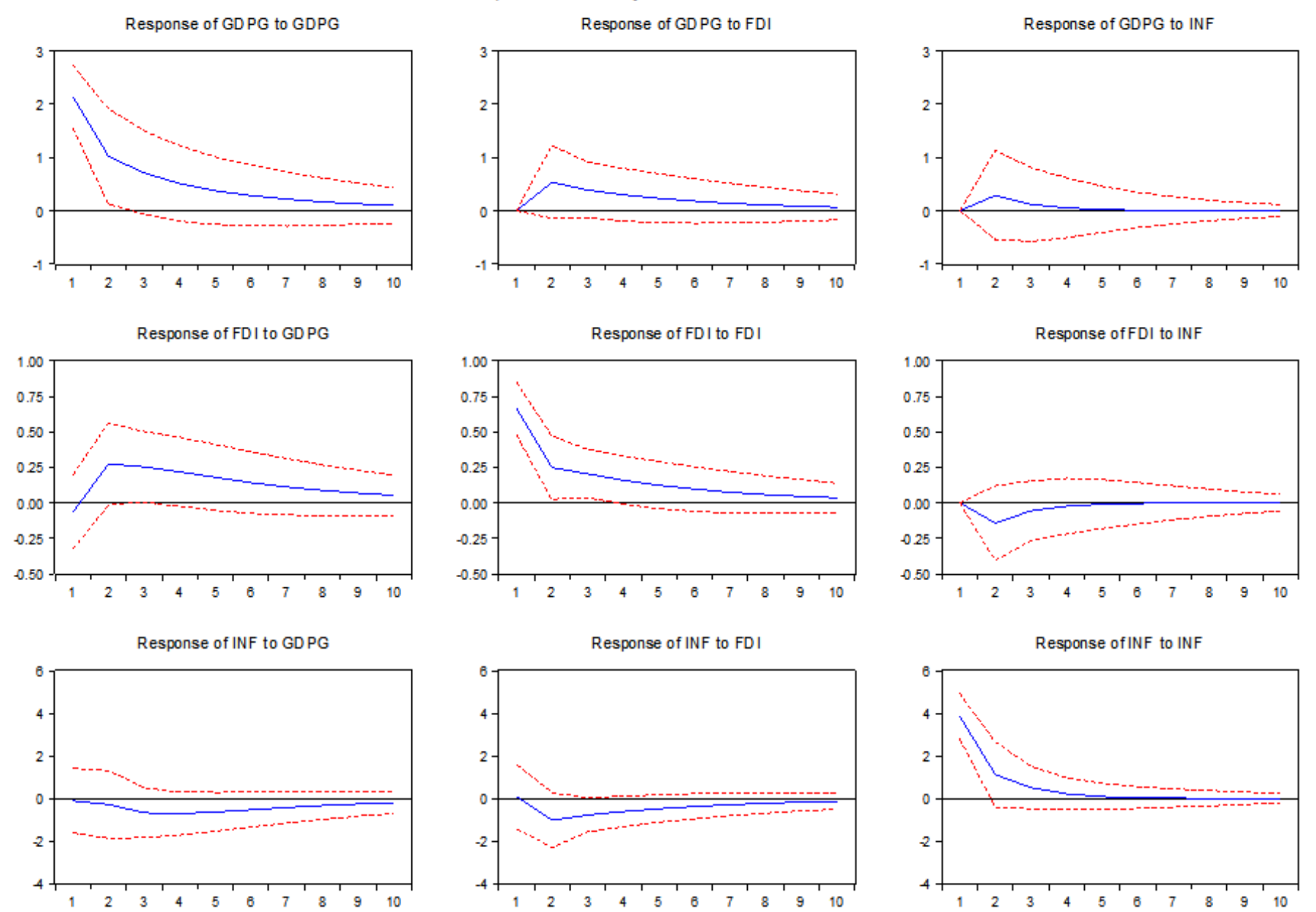

Figure-3. Impulse-response function of economic growth proxied by GDP growth rate, capital inflow and macroeconomic instability.

Moreover, the results in Table 4 (Panel B) show that shocks to economic growth (GDPG) is the major source of variation in capital flows (FDI). It accounts for $0.91 \%$ of the forecast error variance in FDI and increases in the longer horizons to $26.63 \%$ in the fifth year and $29.88 \%$ in the tenth year. Also, FDI own shocks fade out in the long run since it accounted for $99 \%, 70 \%$ and $67 \%$ variation in itself in the first, fifth and tenth periods respectively. However, macroeconomic instability explains a relatively stable but also negligible percentage of forecast error variance in capital flows over the periods. In Table 4 (Panel C), apart from macroeconomic instability 'own' shock, shocks to economic growth (GDPG) and capital flows (FDI) are negligible sources of forecast error variance in macroeconomic instability for the periods implying that other variables not included in the analysis explain significantly large variation in inflation rate in SSA region.

\begin{tabular}{c|c|c|c|c|c|c|c|c|c}
\multicolumn{10}{c}{ Table-4. Variance decomposition analysis. } \\
\hline Period & \multicolumn{3}{|c|}{$\begin{array}{c}\text { Panel A: Variance } \\
\text { decomposition of ECOG }\end{array}$} & \multicolumn{2}{c|}{$\begin{array}{c}\text { Panel B: Variance } \\
\text { decomposition of CAF }\end{array}$} & \multicolumn{3}{c}{$\begin{array}{c}\text { Panel C: Variance } \\
\text { decomposition of MACI }\end{array}$} \\
\hline & ECOG & CAF & MACI & CAF & MACI & ECOG & MACI & ECOG & CAF \\
\hline 1 & 100.000 & 0.000 & 0.000 & 99.089 & 0.000 & 0.910 & 99.870 & 0.082 & 0.046 \\
\hline 2 & 93.852 & 4.754 & 1.393 & 83.565 & 3.415 & 13.019 & 93.347 & 0.536 & 6.115 \\
\hline 3 & 91.996 & 6.548 & 1.454 & 76.645 & 3.338 & 20.016 & 88.091 & 2.986 & 8.921 \\
\hline 4 & 91.073 & 7.506 & 1.420 & 72.713 & 3.100 & 24.186 & 84.134 & 5.449 & 10.415 \\
\hline 5 & 90.562 & 8.048 & 1.989 & 70.436 & 2.937 & 26.625 & 81.508 & 7.271 & 11.220 \\
\hline 6 & 90.266 & 8.364 & 1.369 & 69.103 & 2.838 & 28.057 & 79.861 & 8.471 & 11.666 \\
\hline 7 & 90.091 & 8.550 & 1.357 & 68.316 & 2.780 & 28.903 & 78.853 & 9.225 & 11.921 \\
\hline 8 & 89.988 & 8.661 & 1.350 & 67.848 & 2.746 & 29.404 & 78.242 & 9.688 & 12.069 \\
\hline 9 & 89.926 & 8.727 & 1.346 & 67.569 & 2.726 & 29.703 & 77.874 & 9.969 & 12.156 \\
\hline 10 & 89.889 & 8.767 & 1.343 & 67.403 & 2.713 & 29.882 & 77.652 & 10.139 & 12.208 \\
\hline
\end{tabular}

In order to establish the direction of causality between economic growth and capital inflows in SSA region, the test for causality among the variables was carried out using the VAR Granger Causality or Block Exogeneity Wald Tests. It is conventional that causality between variables exists only when the probability value from the Block Exogeneity Wald Tests is not greater than 5\%. Thus, the causality test in this study was carried out by first estimating a SVAR model with lag length of 1 as stipulated by all information criteria; and the results of VAR Granger Causality or Block Exogeneity Wald Tests was presented in Table 5. 
Table-5. The results of VAR granger causality or block exogeneity wald tests.

\begin{tabular}{|c|c|c|c|c|}
\hline & ECOG & CAF & MACI & ALL \\
\hline ECOG & & $2.624591 \quad[0.1052]$ & $\begin{array}{l}0.480487 \\
{[0.4882]}\end{array}$ & $\begin{array}{l}2.650819 \\
{[0.2657]}\end{array}$ \\
\hline CAF & $\begin{array}{c}5.495120 * * \\
{[0.0191]}\end{array}$ & & $\begin{array}{l}1.216458 \\
{[0.2701]}\end{array}$ & $\begin{array}{c}8.135703^{* *} \\
{[0.0171]}\end{array}$ \\
\hline MACI & $\begin{array}{l}0.237910 \\
{[0.6257]}\end{array}$ & $3.192728 *[0.0740]$ & & $\begin{array}{l}4.415193 \\
{[0.1100]}\end{array}$ \\
\hline
\end{tabular}

values of the Chi-square. ECOG, CAF and MACI represents economic growth proxied by GDP growth, international capital inflows proxied by FDI flows as a share of GDP and macroeconomic instability measured by inflation rate respectively.

Table 5 shows that only economic growth Granger-causes capital inflows at 5\%. Moreover, the results show that all variables together Granger-cause $\mathrm{CAF}$ at $5 \%$. In addition, the results show that capital inflow does not Granger-cause economic growth at 5\%. Also, macroeconomic instability neither Granger-cause economic growth nor capital inflows in SSA region but international capital inflows Granger-causes macroeconomic instability in SSA. The economic implication of this result is that international foreign investors consider the buoyancy of an economy before channelling their resources into such economy. The more developed an economy, the more such economy attracts foreign capital inflows inform of foreign direct investments. However, due to profits repatriation and crowding-out effects on existing domestic investments, international capital inflows could not stimulate economic growth in SSA region. Based on the result of Granger causality, international capital inflows may orchestrate macroeconomic instabilities or imbalances due to capital inflows volatility, sudden capital halts or reversals and other contagion effects from foreign countries.

\section{Summary, Conclusion and Policy Recommendation}

This paper employed Structural Vector Autoregression (SVAR) to examine the dynamic and causal relationship between economic growth and capital inflow in SSA region using time series data for the period of 1990 to 2018. Several findings emanated from the analyses conducted. Through the impulse response and variance decomposition, the study found a positive relationship between economic growth and capital inflow in SSA region. It also found a negative relationship between macroeconomic instability and economic growth; and macroeconomic instability and capital inflow in SSA region. In addition, through VAR Granger Causality or Block Exogeneity Wald Tests, the study found a unidirectional causal relationship running from economic growth to capital inflow in SSA region. The study therefore concluded that a buoyant and viable economy attracts international capital inflows better than less viable economy. Thus, the study recommended that governments and policy makers in SSA region should put in place policies that will enhance or promote economic growth to attract more international capital inflows to augment scarcely available domestic capital resources most especially in terms of knowledge, skills and other technological advancement, and also ensure stability in macroeconomic variables such as inflation rate to avert its negative effect on economic growth and capital inflows in SSA region.

\section{References}

Adams, S., \& Klobodu, E. K. M. (2017). Capital flows and the distribution of income in sub-Saharan Africa. Economic Analysis and Policy, 55(C), 169-178. Available at: https://doi.org/10.1016/j.eap.2017.05.006.

Ahmed, A. D., \& Mmolainyane, K. K. (2014). Financial integration, capital market development and economic performance: Empirical evidence from Botswana. Economic Modelling, 42(C), 1-14. Available at: https://doi.org/10.1016/j.econmod.2014.05.040.

Akinlo, E. A. (2003). Globalization, international investment and stock market growth in sub Saharan Africa. Institute of Developing Economies V.R.F. Series No. 382, Japan.

Akinlo., A. E. (2012). How important is oil in Nigerias economic growth? Journal of Sustainable Development, 5(4), 165. Available at: https://doi.org/10.5539/jsd.v5n4p 165.

Akobeng, E. (2016). Out of inequality and poverty: Evidence for the effectiveness of remittances in Sub-Saharan Africa. The Quarterly Review of Economics and Finance, 60(C), 207-223. Available at: https://doi.org/10.1016/j.qref.2015.10.008.

Alfaro, L., Kalemli-Ozcan, S., \& Sayek, S. (2009). FDI, productivity and financial development. World Economy, 32(1), 111-135. Available at: https://doi.org/10.1111/j.1467-9701.2009.01159.x.

Bai, Y. (2013). Discussion on 'gross capital flows: Dynamics and crises' by broner, didier, erce, and schmukler. Journal of Monetary Economics, 60(1), 134-137. Available at: https://doi.org/10.1111/j.1467-9701.2009.01159.x.

Bailliu, J. N. (2000). Private capital flows, financial development, and economic growth in developing countries. Bank of Canada Working Paper 2000-15.

Batu, M. (2017). International worker remittances and economic growth in a real business cycle framework. Structural Change and Economic Dynamics, $40(\mathrm{C}), 81-91$. Available at: https://doi.org/10.1016/j.strueco.2016.12.004.

Beckmann, J., \& Czudaj, R. (2017). Capital flows and GDP in emerging economies and the role of global spillovers. Journal of Economic Behavior and Organization, 142, 140-163. Available at: https://doi.org/10.1016/j.jebo.2017.07.031.

Borenzstein, E., Gregorio, J. D., \& Lee, J.-W. (1998). How does foreign direct investment affect economic growth? Journal of International Economies, 45, 115-135. Available at: https://doi.org/10.1016/s0022-1996(97)00033-0.

Carp, L. (2014). Financial globalization and capital flows volatility effects on economic growth. Procedia Economics and Finance, 15, 350-356. Available at: https://doi.org/10.1016/s2212-5671(14)00521-8.

Cecchetti, G., \& Kharroubi, E. (2012). Reassessing the impact of finance on growth. Bank for International Settlements Working Papers No. 381.

Christiano, L. J. (2006). Temporal aggregation in structural inferences in macroeconomics. Paper presented at the Carnegle-Rochester Conference series on Public Policy Carnegle-Rochester Conference Series on Public Policy, 26, 63 - 130.

Corporate Finance Institute. (2019). Foreign direct investment: Overview, benefits and disadvantages.

Kandil, M., \& Trabelsi, M. (2015). On capital flows and macroeconomic performance: Evidence before and after the financial crisis in Turkey. Borsa Istanbul Review, 15(4), 249-258. Available at: https://doi.org/10.1016/j.bir.2015.09.001.

Karadam, D. Y., \& Ocal, N. (2014). Financial integration and growth: A nonlinear panel data analysis. ERC Working Papers in Economics, $14 / 15,1-36$.

Kose, M. A., Prasad, E. S., \& Terrones, M. E. (2009). Does openness to international financial flows raise productivity growth? Journal of International Money and Finance, 28(4), 554-580. Available at: https://doi.org/10.5089/9781451871005.001.

Mallick, S., \& Moore, T. (2008). Foreign capital in a growth model. Review of Development Economics, 12(1), 143-159. Available at: https://doi.org/10.1111/j.1467-9361.2008.00437.x. 
Mcmillan, M., Rodrik, D., \& Verduzco-Gallo, I. (2014). Globalization, structural change, and productivity growth, with an update on Africa. World Development, 63, 11-32. Available at: https://doi.org/10.1016/j.worlddev.2013.10.012

Ogbuagu, A., \& Ifionu, E. (2015). Causality between capital flow, human capital development and economic growth; A case of Nigeria. International Journal of Financial Research, 6(3), 116-134. Available at: https://doi.org/10.5430/ijfr.v6n3p116.

Prasad, E. S., Rogoff, K., Wei, S.-J., \& Kose, M. A. (2007). Financial globalization, growth and volatility in developing countries. Retrieved from: http://www.nber.org/chapters/c0114.

Reinhardt, D., Ricci, L. A., \& Tressel, T. (2013). International capital flows and development: Financial openness matters. Journal of International Economics, 91(2), 235-251. Available at: https://doi.org/10.1016/j.jinteco.2013.07.006.

Varela, L. (2018). Reallocation, competition, and productivity: Evidence from a financial liberalization episode. The Review of Economic Studies, 85(2), 1279-1313. Available at: https://doi.org/10.1787/888934048793. 